\title{
ANALISIS KEPUASAN MAHASISWA DITINJAU DARI KINERJA DOSEN DAN FASILITAS PEMBELAJARAN
}

\author{
Studi Kasus pada Mahasiswa Prodi Manajemen Pendidikan Islam
}

Fakultas Tarbiyah dan Keguruan UIN Alauddin Makassar

\author{
RIDWAN IDRIS, HAMSIAH DJAFAR \\ Fakultas Tarbiyah dan Keguruan UIN Alauddin Makassar \\ Email: ridwan.idris@uin-alauddin.ac.id
}

\begin{abstract}
:
This study aims to study the level of student satisfaction in terms of the ability of lecturers and learning facilities in the Department of Islamic Education Management of the Faculty of Tarbiyah and Teacher Training UIN Alauddin Makassar. This research is a quantitative descriptive with employing survey model. The population in the research was 243 people with 24 sample. The data were collected using a questionnaire with Likert Scale. The results showed that the satisfaction of MPI students in terms of lecturer performance was satisfactory category, based on four indicators: learning planning in the satisfactory category, the implementation of learning was very satisfying category, learning outcomes was quite satisfactory category, and guidance and direction was unsatisfactory category. MPI Study Program student satisfaction in terms of Learning facilities in the category was quite decisive, based on four indicators: lecture rooms according to the category are quite satisfactory, chairs and desks are less satisfactory, blackboards/blackboards were quite satisfactory, and learning media were quite satisfactory.
\end{abstract}

Keywords: Student Satisfaction, Lecturer Performance, Learning Facilities

\section{PENDAHULUAN}

erkembangan dunia pendidikan menuntut perguruan tinggi mampu menyelenggarakan pendidikan secara profesional. Upaya yang dilakukan perguruan tinggi adalah meningkatkan kinerja dosen untuk memperbaiki proses perkuliahan, agar pemahaman mahasiswa terhadap materi kuliah meningkat. Banyak mahasiswa mampu menyajikan tingkat hafalan yang baik, tetapi pada kenyataannya mereka sering tidak memahami atau tidak mengerti secara mendalam pengetahuan tersebut. Mahasiswa masih membutuhkan bimbingan dalam menghubungkan antara apa yang mereka pelajari dengan bagaimana pengetahuan itu dapat digunakan dan dimanfaatkan di kehidupan.

Dosen memiliki peranan penting dalam mewujudkan layanan perkuliahan secara profesional. Sebagai tenaga pengajar, dosen diharapkan untuk terus melakukan upaya perbaikan dan peningkatan kualitas perkuliahan melalui berbagai program terencana. Pengembangan bahan perkuliahan berbasis teknologi informasi, multimedia dan pemanfaatan lingkungan kampus dapat meningkatkan hasil belajar mahasiswa serta mempercepat waktu tempuh studi. Paradigma yang mengutamakan hasil belajar saat ini mulai ditinggalkan, diganti dengan paradigma 
yang mengutamakan kualitas proses perkuliahan, karena hasil belajar akan baik bila prosesnya juga baik.

Pengakuan terhadap dosen sebagai tenaga profesional akan diberikan manakala dosen telah memiliki antara lain kualifikasi akademik, kompetensi, dan sertifikat pendidik yang dipersyaratkan suatu pendidikan tinggi tempat bertugas, serta memiliki kemampuan untuk mewujudkan tujuan pendidikan nasional (Pasal 45). Kualifikasi akademik tersebut harus diperoleh melalui pendidikan tinggi program pascasarjana (Pasal 46). Sertifikat pendidik diperoleh dosen setelah mengikuti pendidikan profesi (Pasal 47 Ayat 1). Jenis-jenis kompetensi yang dimaksud dalam undang-undang tersebut meliputi: kompetensi pedagogik, kompetensi kepribadian, dan kompetensi profesional. Kompetensi pedagogik yaitu kemampuan mengelolah perkuliahan yang meliputi pemahaman terhadap mahasiswa, perancangan dan pelaksanaan perkuliahan, evaluasi perkuliahan, dan pengembangan mahasiswa untuk mengaktualisasikan berbagai kompetensi yang dimilikinya. Kompetensi kepribadian yaitu memiliki kepribadian yang mantap, stabil, dewasa, arif, dan berwibawah menjadi teladan bagi mahasiswa dan berakhlak mulia. Kompetensi sosial yaitu kemampuan berkomunikasi secara efektif dengan mahasiswa, sesama pendidik, tenaga kependidikan, orang tua/wali mahasiswa, dan masyarakat sekitar. Kompetensi profesional yaitu kemampuan penguasaan materi perkuliahan secara luas dan mendalam yang memungkinkannya membimbing mahasiswa memenuhi standar kompetensi (Miarso, 2004: 43).

Berdasarkan hasil studi awal kinerja dosen di Prodi MPI ditemukan bahwa beberapa dosen kurang disiplin dan sering merubah jadwal perkuliahan, sehingga berdampak pada penjadwalan ulang yang membuat pihak prodi agak kesulitan. Hal ini didukung oleh hasil wawancara dengan dua orang mahasiswa MPI semester X. Selain kinerja dosen yang menjadi layanan Prodi MPI, fasilitas juga menjadi hal yang sangat penting karena turut mempengaruhi peningkatan kemampuan akademik mahasiswa. Fasilitas pembelajaran sangat mempengaruhi tingkat kepuasan mahasiswa. Untuk belajar yang baik hendaknya tersedia fasilitas belajar yang memadai, antara lain ruang tempat belajar, penerangan cukup, buku-buku pegangan, dan kelengkapan peralatan komputer. Pada prinsipnya fasilitas pembelajaran adalah segala sesuatu yang memudahkan untuk belajar.

Fasilitas pembelajaran sangat mempengaruhi tingkat kepuasan mahasiswa. Untuk belajar yang baik hendaknya tersedia fasilitas belajar yang memadai, antara lain ruang tempat belajar, penerangan cukup, buku-buku pegangan, dan kelengkapan peralatan komputer (Gie, 2002: 33).

Sudah menjadi suatu tuntutan bahwa sekolah/universitas harus memiliki fasilitas belajar yang memadai dan dalam kondisi yang baik. Hal ini bertujuan untuk menunjang jalannya proses belajar mengajar di sekolah/universitas. Menurut PP RI No.19 Tahun 2014 tentang Standar Nasional Pendidikan Bab I Bagian Ketujuh 
tentang Standar Sarana dan Prasarana pasal 30: Standar sarana dan prasarana pembelajaran merupakan kriteria minimal tentang sarana dan prasarana sesuai dengan kebutuhan isi dan proses pembelajaran dalam rangka pemenuhan capaian pembelajaran lulusan (Kementerian Pendidikan dan kebudayaan RI, 2014).

Dalam hal ini, fakultas termasuk di dalamnya prodi hendaknya menyediakan sarana dan prasarana sesuai dengan kebutuhan dan perkembangan mahasiswa agar dapat menumbuhkan, mengembangkan dirinya sesuai dengan bakat dan kemampuan sebagai manusia seutuhnya. Dengan adanya fasilitas belajar yang lengkap, akan menumbuhkan rasa bangga dan rasa memiliki. Pemeliharaan fasilitas belajar di fakultas merupakan tanggung jawab semua pihak yang bersangkutan. Hal ini bertujuan agar fasilitas belajar dapat dimanfaatkan sesuai fungsinya dan dapat bertahan dengan jangka waktu yang lama. Pengadaan fasilitas belajar sangat penting bagi kurikulum dan mahasiswa dalam mencapai tujuan pembelajaran.

Berdasarkan hasil observasi terhadap fasilitas yang ada, dapat dilihat bahwa fasilitas yang ada masih sangat terbatas, selain terbatas juga keadaan beberapa fasilitas sudah perlu perbaikan dan tidak bisa memenuhi kebutuhan mahasiswa yang cukup besar. Demikian pula pemeliharaan fasilitas tersebut juga menjadi hal yang perlu ditingkatkan, yang bisa dilihat dari ketersediaan dan kemampuan petugas kebersihan yang masih sangat rendah. Hal tersebut tentu saja sangat mungkin jadi perbincangan dan kritik mahasiswa sebagai pengguna dari fasilitas tersebut. Hasil observasi tersebut, juga didukung oleh pernyataan dua mahasiswa MPI semester $X$.

Berdasarkan latar belakang tersebut, maka rumusan masalah penelitian ini adalah bagaimana kepuasan mahasiswa ditinjau dari kinerja dosen di Prodi Manajemen Pendidikan Islam Fakultas Tarbiyah dan Keguruan UIN Alauddin Makassar? dan bagaimana kepuasan mahasiswa ditinjau dari fasilitas pembelajaran di Prodi Manajemen Pendidikan Islam Fakultas Tarbiyah dan Keguruan UIN Alauddin Makassar?

\section{KAIIAN TEORETIS}

\section{Kepuasan Mahasiswa}

Keberhasilan suatu prodi bisa dilihat atau terletak pada ukuran kepuasan mahasiswa. Mengukur kepuasan mahasiswa, bisa dilihat dalam dua hal yaitu kepuasan terhadap kinerja dosen dan kepuasan terhadap fasilitas pembelajaran yang disiapkan oleh prodi itu. Dalam hal inilah prodi MPI ingin melihat sejauh mana kepuasan tersebut didapatkan mahasiswanya.

Membahas kepuasan mahasiswa bisa diartikan sebagai perasaan senang, puas dan kelegaan mahasiswa pada prodi yang dimasukinya terhadap pelayanan baik fisik maupun non-fisik yang diberikan prodi selama mereka mengikuti proses perkuliahan. Kesimpulan tersebut sesuai dengan pernyataan dari Sopiatin (2010: 
33) yang menekankan pada aspek sikap positif dari mahasiswa terhadap prodi yang dimasukinya. Demikian pula yang dikemukakan oleh Sugito (dalam Srinadi, 2008: 217-231) bahwa kepuasan mahasiswa adalah suatu keadaan terpenuhinya keinginan, harapan, dan kebutuhan mahasiswa. Hal yang sama juga dikemukakan oleh Sarjono (2007: 13-14) bahwa kepuasan mahasiswa adalah perbandingan antara harapan yang diinginkan mahasiswa tentang pelayanan karyawan, kompetensi dosen yang didukung oleh sarana.

Berry dan Parasuraman mengemukakan lima indikator kepuasan yang bisa menjadi indikator dari kepuasan mahasiswa terhadap prodi yang dimasukinya, yaitu; (1) keandalan, (2) daya tanggap, (3) kepastian, (4) empati, dan (5) berwujud (Sopiatin, 2010: 33).

\section{Kinerja Dosen}

Dosen adalah pendidik profesional dan ilmuwan dengan tugas utama mentransformasikan, mengembangkan, dan menyebarluaskan ilmu pengetahuan, teknologi melalui pendidikan, penelitian, dan pengabdian kepada masyarakat (Kementerian Pendidikan dan kebudayaan RI, 2014). Kinerja dosen dapat dinyatakan sebagai hasil kerja yang dapat dicapai oleh seorang dosen di lembaga pendidikan tinggi sesuai dengan tugas dan tanggung jawabnya dalam mencapai tujuan pendidikan. Dengan kata lain, hasil kerja yang dicapai seseorang dalam melaksanakan tugas-tugas yang dibebankan kepadanya didasarkan hasil kecakapan, pengalaman, dan kesungguhannya (Baharuddin dan Rahmatia, 2018:6).

Kinerja dosen berdasarkan pada kualitas dosen itu sendiri yang sesuai dengan tugas dan fungsinya masing-masing. Kualitas merupakan istilah yang berkaitan dengan sudut pandang dan kepentingan pengguna istilah. Berdasarkan beberapa pengertian tersebut, maka dapat disimpulkan bahwa kinerja dosen merupakan kualitas hasil kerja dan keberhasilan dosen sesuai standar tugasnya dalam pengajaran, penelitian dan pengabdian masyarakat sesuai dengan tugas dan fungsi dosen dalam Tri Dharma Perguruan Tinggi.

Pada umumnya unsur-unsur yang perlu diadakan penilaian dalam proses penilaian kinerja adalah kesetiaan, prestasi kerja, tanggung jawab, ketaatan, kejujuran, kerjasama, prakarsa, dan kepemimpinan.

\section{Fasilitas Pembelajaran}

Meningkatkan pembelajaran diperlukan fasilitas belajar yang baik. Fasilitas ini sangat menunjang keberhasilan atau ketercapaian pembelajaran. Menurut Gie (2002), "untuk belajar yang baik diperlukan perabotan, perlengkapan, dan ruang belajar". Hal ini juga berlaku di dalam proses perkuliahan. Untuk itu fasilitas pembelajaran juga berlaku bagi proses perkuliahan.

Schneider (2002) mengungkapkan bahwa "those involved in school palnning design see this as an opportunity to enhance academic outcome by creating better 
learning environments". Pendapat di atas menyatakan bahwa menciptakan lingkungan belajar adalah syarat mutlak dalam menggapai hasil akademik yang baik. Lingkungan belajar yang dikemukakan oleh Schneider di atas adalah fasilitas pembelajaran. Pratiya (2008) berpendapat bahwa "fasilitas Pembelajaran identik dengan sarana prasarana pendidikan. Senada dengan hal tersebut, Arikunto juga berpendapat "fasilitas dapat disamakan dengan sarana yang ada di sekolah" (Pratiya, 2008).

Fasilitas belajar adalah peralatan dan perlengkapan yang secara langsung dipergunakan dan menunjang proses pendidikan, khususnya proses belajar mengajar, seperti ruang kuliah, LCD projector, meja, kursi, serta alat-alat dan media pengajaran lainnya. Prasarana pendidikan adalah fasilitas yang secara tidak langsung menunjang jalannya proses pendidikan atau pengajaran, seperti perpustakaan, tetapi jika dimanfaatkan secara langsung untuk proses Pembelajaran mengajar, komponen tersebut merupakan sarana pendidikan (Mulyasa, 2005: 28).

Berdasarkan uraian tersebut, maka dapat disimpulkan bahwa fasilitas pembelajaran adalah segala sesuatu yang dapat menunjang dan mempermudah kegiatan pembelajaran mengajar. Fasilitas yang dimaksud adalah sarana pendidikan yang ada di ruang kuliah dan perabot serta peralatan pendukung di dalamnya, media pembelajaran, buku atau sumber pembelajaran lainya.

\section{METODE PENELITIAN}

Pendekatan yang digunakan adalah pendekatan kuantitatif, dengan jenis penelitian Ex Post Facto. Lokasi penelitian bertempat di Jurusan Manajemen Pendidikan Islam Fakultas Tarbiyah dan Keguruan Universitas Islam Negeri (UIN) Alauddin. Populasi yang dimaksud dalam penelitian ini adalah seluruh mahasiswa Jurusan Manajemen Pendidikan Islam Fakultas Tarbiyah dan Keguruan UIN Alauddin Angkatan 2015, 2016, dan 2017, dengan jumlah 243 orang. Sementara teknik sampel yang digunakan adalah stratified random sampling, yaitu pengambilan sampel dengan cara mengambil sampel berstrata dengan mengambil 10\% dari setiap angkatan. Dengan demikian, setiap angkatan diambil 8 orang, 3 laki-laki dan 5 perempuan, dengan jumlah keseluruhan adalah 24 orang. Dalam penelitian ini, metode pengumpulan data yang dilakukan angket atau kuesioner dengan instrumen penelitian Skala Likert. Semua data dianalisis dengan teknik analisis deskriptif.

\section{HASIL DAN PEMBAHASAN}

Kepuasan Mahasiswa Ditinjau dari Kinerja Dosen di Prodi Manajemen Pendidikan Islam Fakultas Tarbiyah dan Keguruan UIN Alauddin Makassar

Terdapat empat hal yang menjadi indikator dari kinerja dosen, yaitu: (1) merencanakan pembelajaran; (2) melaksanakan pembelajaran; (3) menilai hasil 
pembelajaran; dan (4) membimbing dan mengarahkan. Berdasarkan hasil penelitian dari indikator perencanaan pembelajaran ditemukan fakta bahwa dosen Prodi MPI telah membuat pedoman perkuliahan/kontrak kuliah ketika memulai perkuliahan. Hal ini juga mengindikasikan adanya kepuasan dari mahasiswa terhadap dosen Prodi MPI. Hal ini bisa dilihat pada penilaian mahasiswa yang hanya berada pada kategori selalu dan sering.

Selanjutnya pedoman perkuliahan yang dibuat oleh dosen kemudian didiskusikan bersama mahasiswa juga berada pada kategori yang cukup memuaskan. Penilaian mahasiswa berada pada kategori selalu dan sedang dengan nilai 95\%. Hal ini membuktikan bahwa kebanyakan pedoman perkuliahan yang dibuat oleh dosen didiskusikan terlebih dahulu. Walaupun penilaian ini menurun dibandingkan dengan item pertama.

Proses selanjutnya setelah pedoman perkuliahan didiskusikan adalah pedoman perkuliahan digunakan atau dijalankan sesuai dengan hasil kesepakatan. Dalam hal ini menunjukkan adanya kepuasan yang tidak seimbang antara harapan mahasiswa dengan apa yang dijalankan dosen Prodi MPI. Jadi selama ini, sebagian besar dosen tidak menjalankan hasil kesepakatan yang dibuat bersama oleh dosen dan mahasiswa. Hal ini dibuktikan dengan penilaian mahasiswa yang cukup seimbang antara yang menilai puas dan tidak puas.

Hasil kesepakatan yang dituangkan dalam pedoman perkuliahan seharusnya lebih banyak memuat aspirasi mahasiswa. Berdasarkan hasil penelitian ditemukan dosen dalam menjalankan perkuliahan dengan pedoman perkuliahan/kontrak kuliah yang dibuat kurang memperhatikan aspirasi yang diharapkan mahasiswa. Kesimpulan ini bisa dilihat dari penilaian mahasiswa yang lebih banyak di bagian kadang-kadang dan jarang.

Pedoman perkuliahan yang baik adalah pedoman yang disepakati bersama. Hasil penelitian menunjukkan dosen Prodi MPI telah melakukan kesepakatan dalam bentuk kontrak kuliah dengan mahasiswa. Ini bisa dilihat dari lebih $75 \%$ mahasiswa berada pada kategori selalu dan sering.

Berdasarkan kelima item pernyataan yang diteliti, terdapat 3 item berada pada kategori tinggi artinya mahasiswa puas dengan hal itu. Ketiga item tersebut adalah sebagai berikut: (1) dosen telah membuat pedoman perkuliahan; (2) dosen telah mendiskusikan pedoman yang dibuat dengan mahasiswa; dan (3) dosen telah membuat kesepakatan bersama dalam bentuk kontrak kuliah. Sementara yang berada pada kategori sedang dan tidak terlalu memuaskan adalah pedoman perkuliahan yang dibuat dosen tidak banyak memuat aspirasi mahasiswa serta pedoman yang dijalankan itu tidak sesuai dengan yang dikontrakkan.

Berdasarkan hasil penelitian dari indikator pelaksanaan pembelajaran ditemukan fakta bahwa mahasiswa menganggap lebih banyak dosen Prodi MPI yang datang atau memulai perkuliahan tidak tepat waktu. Hal ini bisa dilihat dari 55\% mahasiswa menilai pada kategori kadang-kadang dan jarang. Dalam proses 
perkuliahan ditemukan fakta bahwa mahasiswa menganggap lebih banyak dosen Prodi MPI yang telah melakukan apersepsi dan hal tersebut memberikan kepuasan yang baik dari mahasiswa. Hal ini terlihat dari data yang menunjukkan 50\% lebih mahasiswa dalam kategori selalu dan sering.

Dosen Prodi MPI telah melakukan bimbingan, arahan, dan motivasi sebelum memulai perkuliahan, walaupun terlihat juga bahwa dosen tidak selalu melakukannya. Hal ini tentu saja menjadi penilaian yang positif dari mahasiswa dan juga menambah kepuasan terhadap kinerja dosen. Hal ini dibuktikan dengan $75 \%$ mahasiswa berada pada kategori sering dan selalu.

Pelaksanaan perkuliahan yang dibarengi dengan tanya jawab dan/atau interaksi antara mahasiswa dan dosen di Prodi MPI juga menunjukkan sesuatu yang baik atau memberi kepuasan kepada mahasiswa. Hal ini bisa dilihat dari $75 \%$ mahasiswa menilai pada kategori sering dan selalu. Pelaksanaan perkuliahan dengan metode, teknik, dan media pembelajaran yang bervariasi juga sudah memuaskan mahasiswa. Hal tersebut terlihat dari $77 \%$ mahasiswa berada pada kategori selalu dan sering.

Berdasarkan kelima item pernyataan yang diteliti, terdapat 4 item berada pada kategori tinggi artinya mahasiswa puas dengan hal itu. Keempat item tersebut yaitu sebagai berikut: (1) dosen telah melakukan apersepsi atau penyampaian materi sebelumnya; (2) dosen Prodi MPI telah melakukan bimbingan, arahan, dan motivasi sebelum memulai perkuliahan; (3) pelaksanaan perkuliahan telah dibarengi dengan tanya jawab dan/atau interaksi antara mahasiswa dan dosen; dan (4) pelaksanaan perkuliahan dilakukan dengan metode, teknik, dan media pembelajaran yang bervariasi. Walaupun berada pada kategori tinggi, tetapi masih dibutuhkan peningkatan. Sementara satu hal yang masih pada kategori rendah atau mahasiswa tidak puas dengan hal itu, yaitu dosen Prodi MPI yang datang atau memulai perkuliahan tidak tepat waktu. Dengan demikian pada aspek ini rata-rata mahasiswa sudah puas.

Berdasarkan hasil penelitian dari indikator penilaian hasil pembelajaran ditemukan fakta bahwa dosen telah memberikan tugas yang cukup ketika perkuliahan terjadi. Hal ini terlihat dari lebih dari 66\% mahasiswa berada pada kategori selalu dan sering. Hal ini mengindikasikan bahwa adanya kepuasan. Dosen Prodi MPI telah memberikan penjelasan sebelum tugas itu diberikan hal ini ditunjukkan pada hasil penelitian yang memberikan penilaian $80 \%$ lebih pada kategori selalu dan sering. Dengan demikian dapat disimpulkan bahwa mahasiswa merasa puas dengan kondisi ini.

Setelah diberikan tugas, semestinya tugas tersebut diperiksa dan diberi nilai oleh dosen. Hasil penelitian terkait hal ini menunjukkan dosen Prodi MPI kebanyakan tidak memeriksa dan memberi penilaian tugas tersebut. Ini dibuktikan dengan penilaian mahasiswa yang lebih $50 \%$ berada pada kategori kadang-kadang dan jarang. Hal ini tentu saja tidak memuaskan mahasiswa. 
Sedikit berbeda dengan hasil tersebut, pada aspek pemberian catatan pada tugas yang diberikan menunjukkan hasil yang sedang-sedang saja. Hal tersebut terlihat pada berimbangnya antara yang menyatakan memberi catatan dengan yang jarang memberi catatan. Hal ini mengindikasikan kepuasan mahasiswa perlu ditingkatkan.

Dalam memberi penilaian terhadap tugas, dosen Prodi MPI Pemberian nilai yang obyektif terhadap mahasiswa perlu dilakukan telah melakukannya dengan obyektif. Hasil ini terlihat dari lebih dari $80 \%$ menilai pada kategori selalu dan sering, dan ini tentu saja memberikan kepuasan yang cukup baik bagi mahasiswa.

Dari lima item pernyataan yang diteliti, terdapat 3 item berada pada kategori tinggi artinya mahasiswa puas dengan hal itu. Ketiga item tersebut, yaitu (1) dosen telah memberi tugas, (2) dosen Prodi MPI memberi penjelasan terhadap tugas yang diberikan, dan (3) penilaian sudah obyektif. Sementara satu hal yang masih pada kategori rendah atau mahasiswa tidak puas dengan hal itu, adalah tidak memeriksa dan memberi penilaian pada tugas yang diberikan. Satu hal lain yang berada di kategori sedang, yaitu dosen kurang memberi catatan terhadap tugas yang diberikan.

Berdasarkan hasil penelitian dari indikator pembimbingan dan pengarahan ditemukan fakta; pembimbingan dan pengarahan dosen sudah cukup memuaskan mahasiswa. Hal ini ditandai dari lebih $70 \%$ mahasiswa menilai sering dan selalu. Sementara untuk pemberian motivasi ketika perkuliahan ditemukan bahwa mahasiswa sudah cukup puas, hal ini dibuktikan dengan adanya lebih dari $70 \%$ mahasiswa berada pada kategori selalu dan sering.

Dosen Prodi MPI mau menampung curahan hati dari mahasiswa ketika mahasiswa memiliki masalah. Hal ini bisa dilihat dari sekitar 57\% mahasiswa menilai selalu dan sering. Akan tetapi masih perlu peningkatan mengingat ada lebih dari 40\% mahasiswa menganggap kadang-kadang dan jarang. Dalam hal ini kepuasan mahasiswa disimpulkan kategori sedang. Sama halnya dengan data sebelumnya, dosen Prodi MPI juga perlu peningkatan pada pemberian solusi ketika terdapat mahasiswa yang melakukan bimbingan dan butuh solusi. Hal ini bisa dilihat pada kategori selalu dan sering hanya terdapat kurang dari 57\%. Hal ini dapat disimpulkan bahwa mahasiswa kurang puas.

Dalam melakukan bimbingan, dosen diharapkan melaksanakan terlebih dahulu apa yang selalu diucapkan. Kaitannya dengan ini mahasiswa menilai dosen Prodi MPI belum sepenuhnya menjalankan sendiri bimbingan dan arahan yang diberikan. Ini terlihat dari kurang dari 55\% mahasiswa menilai selalu dan sering pada bagian ini. Jadi, dapat disimpulkan bahwa mahasiswa kurang puas dalam hal ini.

Berdasarkan kelima item pernyataan yang diteliti, terdapat 2 item berada pada kategori tinggi artinya mahasiswa puas dengan hal itu. Kedua item itu adalah; pemberian bimbingan dan pengarahan dan pemberian motivasi ketika perkuliahan 
berlangsung. Sementara 3 yang lain berada pada kategori sedang, yaitu (1) dosen mau menampung permasalahan mahasiswa; (2) dosen memberi solusi ketika melakukan bimbinga dan pengarahan; dan (3) dosen melakukan sendiri apa yang diucapkannya dalam pembimbingan. Dengan demikian aspek ini berada pada kategori sedang.

\section{Kepuasan Mahasiswa Ditinjau dari Fasilitas Pembelajaran di Prodi Manajemen Pendidikan Islam Fakultas Tarbiyah dan Keguruan UIN Alauddin Makassar}

Terdapat empat yang menjadi indikator dari aspek ini, yaitu (1) ruang kuliah, (2) kursi dan meja; (3) papan tulis (Whiteboard); dan (4) media pembelajaran.

Berdasarkan hasil penelitian pada aspek ruang kuliah ditemukan fakta bahwa ketersediaan ruang kuliah sudah cukup bagus. Hal ini dibuktikan dengan sekitar $80 \%$ responden menyatakan selalu dan sering. Artinya bahwa dalam hal ini mahasiswa cukup puas. Mahasiswa Prodi MPI menilai ruang kuliah cukup memberi keamanan dan kenyamanan. Hal ini bisa dilihat dengan adanya $75 \%$ yang memberi kategori selalu dan sering. Hasil ini menunjukkan bahwa mahasiswa cukup puas.

Ketika ada keluhan terkait kerusakan ruang kuliah, kebanyakan mahasiswa kurang puas. Terbukti dengan lebih dari setengah mahasiswa menyatakan kadangkadang, jarang dan bahkan ada mahasiswa yang menilai pihak jurusan tidak merespon ketika ada laporan kerusakan. Mahasiswa menilai ruang kuliah yang selama ini digunakan pada kategori sedang-sedang saja dalam hal kerapian. Hal tersebut bisa dilihat dengan penilaian mahasiswa yang setengah-setengah saja. Mahasiswa yang menilai baik hanya $50 \%$ dan yang menilai biasa-biasa saja juga hampir 50\%. Dengan demikian perlu adanya perhatian khusus mengenai hal ini.

Berdasarkan keempat item pernyataan yang diteliti, terdapat dua item pada kategori cukup memuaskan, yaitu ketersediaan ruang kuliah dan ruang kuliah yang aman dan nyaman. Satu hal yang dianggap tidak memuaskan yaitu respon jurusan ketika ada keluhan kerusakan ruang kuliah. Satu hal lain yang kepuasannya sedang-sedang saja yaitu kerapian ruang kuliah.

Berdasarkan hasil penelitian pada aspek kursi dan meja ditemukan fakta bahwa kursi dan meja untuk mahasiswa Prodi MPI sudah cukup memadai. Hal ini dibuktikan dengan penilaian mahasiswa yang $70 \%$ persen berada pada kategori selalu dan sering. Dengan demikian keberadaan kursi dan meja ini sudah cukup membuat mahasiswa puas. Walaupun perlu ada peningkatan dari segi jumlah, karena sebagian kecil mahasiswa masih tidak puas.

Sebagian kecil mahasiswa Prodi MPI menilai kualitas meja dan kursi selalu bagus. Sebagian besar mereka hanya menilai sering, artinya sangat besar kemungkinan bahwa kualitas kursi dan meja yang selama ini digunakan mudah rusak, sehingga ketika mereka ingin menggunakan terdapat meja dan kursi yang dalam keadaan terbengkalai dan perlu perbaikan. Oleh karena itu, dalam hal ini 
perlu ada perbaikan karena hasil menunjukkan bahwa mahasiswa belum terlalu puas dengan kondisi ini.

Pada aspek respon jurusan terlihat bahwa banyak mahasiswa di kategori kadang-kadang, jarang, dan bahkan ada yang merasa tidak pernah direspon. Dalam hal ini mahasiswa kurang puas. Sementara untuk fungsi kursi dan meja, mahasiswa menilai sudah cukup memuaskan. Walaupun demikian, harus ada peningkatan, sehingga kepuasan mahasiswa terhadap hal ini dapat meningkat pula.

Berdasarkan keempat item pernyataan yang diteliti, terdapat dua item pada kategori cukup memuaskan, yaitu; ketersediaan kursi dan meja, serta kursi dan meja sudah berfungsi dengan baik. Sementara satu hal yang kurang memuaskan adalah kualitas dari kursi dan meja tersebut. Satu hal lain yang tidak memuaskan adalah respon jurusan ketika ada keluhan terkait kerusakan kursi dan meja.

Berdasarkan hasil penelitian pada aspek papan tulis/whiteboard ditemukan fakta bahwa; hampir 90\% mahasiswa menilai papan tulis selalu tersedia di ruang kuliah. Bahkan tidak ada yang menilai kadang-kadang, jarang, dan tidak pernah. Hal ini tentu saja sangat positif, mengingat mahasiswa sangat puas dengan kondisi ini.

Kualitas dari papan tulis/whiteboard yang ada di dalam ruang kuliah ternyata tidak berbanding lurus dengan ketersediaannya. Mengingat tingkat kepuasan mahasiswa dalam tingkatan yang rendah. Jika diamati terlihat lebih dari setengah mahasiswa menyatakan kadang-kadang, jarang, dan tidak pernah.

Sementara itu respon jurusan ketika ada laporan papan tulis/whiteboard yang ada di dalam ruang kuliah rusak juga masih rendah. Hal ini tentu saja mengindikasikan bahwa mahasiswa belum terlalu puas terhadap hal ini. Kesiapan papan tulis ketika akan digunakan oleh mahasiswa berada pada kategori yang baik. Hasil ini juga mengindikasikan adanya kepuasan dari mahasiswa terhadap kesiapan papan tulis ini.

Berdasarkan keempat item pernyataan yang diteliti, terdapat dua item pada kategori sangat memuaskan, yaitu ketersediaan papan tulis/whiteboard, dan kesiapan dari papan tulis ketika akan digunakan. Sementara dua hal yang tidak memuaskan yaitu kualitas dari papan tulis, dan respon jurusan ketika terjadi kerusakan papan tulis tersebut.

Berdasarkan hasil penelitian pada aspek media pembelajaran ditemukan fakta bahwa; mahasiswa Prodi MPI masih menganggap bahwa ketersediaan media ini belum maksimal, kadang tersedia, dan tidak tersedia. Oleh karena itu, kepuasan mahasiswa masih dalam kategori sedang. Pada hal kualitas media pembelajaran, mahasiswa menilai media pembelajaran perlu ditingkatkan kesiapannya dengan kualitas yang baik. Hasil penelitian tidak terlalu memuaskan pada kesiapan media untuk dipergunakan langsung. Kadang kala media pembelajaran bisa dipakai, kadang kala juga tidak bisa dipakai karena mengalami kerusakan. 
Sementara responden jurusan ketika ada keluhan kerusakan media pembelajaran cukup bagus. Hal tersebut terlihat pada data yang menunjukkan penilaian mahasiswa ada pada kategori sering dan selalu. Hal ini menunjukkan bahwa mahasiswa cukup puas pada respon jurusan. Walaupun demikian perlu ada peningkatan. Pada aspek kesiapan media pembelajaran mahasiswa cukup puas dengan hal ini, walaupun masih perlu ada peningkatan sehingga dapat lebih meningkatkan kepuasan mahasiswa.

Berdasarkan keempat item pernyataan yang diteliti, terdapat dua item pada kategori cukup memuaskan, yaitu respon jurusan ketika terjadi kerusakan media pembelajaran, dan kesiapan dari media pembelajaran ketika akan digunakan. Sementara dua hal yang kurang memuaskan, yaitu ketersediaan media pembelajaran ketika akan digunakan, dan kualitas dari media pembelajaran tersebut.

\section{PENUTUP/SIMPULAN}

Berdasarkan hasil penelitian yang telah dikemukakan sebelumnya, maka dapat disimpulkan bahwa:

1. Kepuasan mahasiswa Prodi MPI ditinjau dari kinerja dosen berada pada kategori cukup memuaskan. Hal ini berdasarkan pada empat indikator yaitu; indikator perencanaan pembelajaran pada kategori cukup memuaskan, indikator pelaksanaan pembelajaran pada kategori sangat memuaskan, indikator penilaian hasil pembelajaran pada kategori cukup memuaskan, dan indikator pembimbingan dan pengarahan pada kategori kurang memuaskan. Hal-hal yang masih perlu perbaikan, yaitu kesesuaian kontrak kuliah dengan yang dijalankan, kedisiplinan waktu dosen, penilaian pada tugas, dan arahan yang sesuai dengan perilaku dosen.

2. Kepuasan mahasiswa Prodi MPI ditinjau dari fasilitas Pembelajaran berada pada kategori cukup memuskan. Hal ini didasarkan pada empat indikator, yaitu; indikator ruang kuliah berada pada kategori cukup memuaskan, indikator kursi dan meja kurang memuaskan, indikator papan tulis/whiteboard pada kategori cukup memuaskan, dan indikator media pembelajaran cukup memuaskan. Halhal yang harus diperbaiki, yaitu respon jurusan ketika ada keluhan mahasiswa terkait fasilitas, kursi dan meja yang berkualitas, media pembelajaran yang siap sedia dan berkualitas.

\section{DAFTAR PUSTAKA}

Baharuddin dan Rahmatia. (2018). Pengaruh Kecerdasan Spiritual terhadap Peningkatan Kinerja Guru di SMA Negeri 3 Takalar Kabupaten Takalar, (Jurnal Idaarah, 2(1).

Gie, The Liang, (2002). Cara Belajar yang Efisien. Yogyakarta: Liberty. 
Kementerian pendidikan dan kebudayaan RI "Peraturan Menteri Pendidikan dan Kebudayaan Republik Indonesia Nomor 49 Tahun 2014 tentang Standar Nasional Pendidikan Tinggi" faperta.ugm.ac.id/2014/site/fokus/.../permen_tahun2014_nomor049.pdf (10 Desember 2015).

Miarso, Y. (2004). Pengembangan Profesionalisme dosen Dalam rangka Peningkatan Mutu Perguruan Tinggi, Jakarta: Rineka Cipta.

Mulyasa, E. (2005). Manajemen Berbasis Sekolah, Jakarta: Depdiknas.

Pratiya. (2008). Kontribusi Fasilitas Belajar dan Motivasi Berprestasi Terhadap Hasil Belajar Kimia pada Siswa SMA Negri 1 Karangnongko Kabupaten Klaten. Tesis Pogram Pascasarjana. Surakarta.

Republik Indonesia. (2005). Undang-Undang RI No 14 Tahun 2005 tentang Guru dan Dosen. Jakarta: BP Cipta Jaya.

Sarjono, Yetti. (2007). Faktor-faktor Strategi Pelayanan Dosen dan Dampaknya Terhadap Kepuasan Mahasiswa FKIP Universitas Muhammadiyah Surakarta Tahun Akademik 2005-2006. Varidika, 9(1).

Schneider, Mark. (2002). Do school facilities affect Academic Outcomes. National Clearinghouse for Educational Facilities.

Sopiatin. (2010). Manajemen Belajar Berbasis Kepuasan Siswa, Bogor: Ghalia Indonesia.

Srinadi. (2008) Faktor-Faktor Penentu Kepuasan Mahasiswa Terhadap Pelayanan Fakultas Sebagai Lembaga Pendidikan. Jurnal Cakrawala Pendidikan, Th. XXVII.

Undang-Undang Republik Indonesia Nomor 20 Tahun 2003 tentang Sistem Pendidikan Nasional, Jakarta: BP Cipta Jaya. 